University of Rhode Island

DigitalCommons@URI

Open Access Master's Theses

1978

\title{
THE PROGRESSIVE ORIGINS OF MODERN CITY PLANNING
}

James F. Dunn

University of Rhode Island

Priscilla A. Golding

University of Rhode Island

Follow this and additional works at: https://digitalcommons.uri.edu/theses

\section{Recommended Citation}

Dunn, James F. and Golding, Priscilla A., "THE PROGRESSIVE ORIGINS OF MODERN CITY PLANNING" (1978). Open Access Master's Theses. Paper 379.

https://digitalcommons.uri.edu/theses/379

This Thesis is brought to you for free and open access by DigitalCommons@URI. It has been accepted for inclusion in Open Access Master's Theses by an authorized administrator of DigitalCommons@URI. For more information, please contact digitalcommons-group@uri.edu. 
THE PROGRESSIVE ORIGINS OF MODERN CITY PLANNING

$\mathrm{BY}$

JAMES F. DUNN AND PRISCILLA A. GOLDING

A THESIS PROJECT SUBMITTED IN PARTIAL FULFILLMENT OF THE

REQUIREMENTS FOR THE DEGREE OF

MASTER OF COMMUNITY PLANNING

UNIVERSITY OF RHODE ISLAND

1978 


\section{MASTER OF CONIUNITY PLANNING THESIS PROJECT \\ $\mathrm{OF}$}

JANES F. DUNN AND PRISCILIA A. GOLDING

\section{APPROVED BY:}

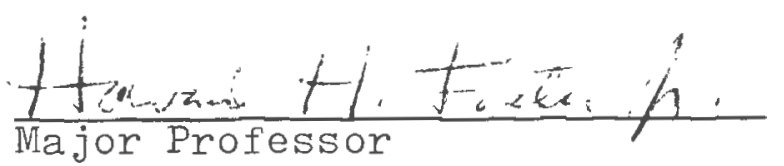

Director, Community Planning and Area Development 
ACKNOWLEDGMENTS

The authors acknowledge with many thanks the precious time and energy contributed by the following people:

Professor Howard H. Foster, Jr., Community Planning Curriculum, University of Rhode Island, under whose guidance we have learned as well as labored, for all his help;

Ms. Judy Smith, University of Rhode Island History Department, for her invaluable assistance and critical analysis;

Professor Marcia Marker Feld, Community Planning Curriculum, University of Rhode Island, for her encouragement and inspiration. 
CONTENTS

Page

INTRODUCTION

CHAPTER I : THE NEW URBAN EXPERIENCE

CHAPTER II: THE PROGRESSIVES AND CITY PLANNING

CHAPTER III: CITY PLANNING AS PRESENTED BY BENJAMIN 
INTRODUCTION

"By 1917 American city planning had established a firm foothold as a profession in service to the urban elite." (Joseph L. Arnold, 1973)*

The progressive period in American history was characterized by the search for order and efficiency. Emphasis was placed on the development of professional personnel with whom the new process was entrusted. Coalitions of the new professionals developed comprehensive frameworks for society. City planning was one facet of the progressive approach to societal reform. Thus an examination of the progressive heritage of city planning is necessary for a general understanding of the rationale and basis for modern planning techniques. It was in the progressive period that zoning was initiated and planning commissions were formed. The professionalization of the field culminated in the establishment of the American City Planning Institute (predecessor to the American Institute of Planners.)

In order to understand the present implications of city planning, we have to place our actions and theories in an historical context. It is helpful for planners to realize why and how zoning emerged as a major tool for planning and why social planning has come to be a distinct discipline

*Mohl, Raymond A. and James F. Richardson. The Urban Experience (Belmont, California: Wordsworth Publishing Co., 1973), p. 38 . 
within the profession. For, it is also important to recall the political and social atmosphere that encouraged a comprehensive approach to planning, as well as the substantive issues which promoted the process.

The "new" city planners were prompted by an inability of the old order to coordinate growth and development in the cities. Reformers were frustrated by the lack of a recognizable order in the cities, but although influenced by a varying array of political and social beliefs, all of the urban professionals relied on documented procedures and standards for the solutions to urban problems.

of particular interest to the authors is the historical legitimacy of social planning, or what has recently been labeled as such in an effort to distinguish the traditional or physical oriented planning from a more people-centered approach. As will be further explored in the following chapters, it is issues such as housing and jobs for the poor which prompted the discussions and debates at the planning meetings. In turn, the "new" planning produced numerous standards and regulations for solving urban problems.

"The failure of city planners to serve the poor, although it upset some practitioners, resulted in no serious decline in the profession's source of support; but the failure to serve adequately the rich and powerful carried with it the threat of premature extinction." ${ }^{1}$ Through a commitment to efficiency and scientific management, planning as a discipline offered a rational approach to suburban and urban development. 
Specific social issues, originally in the forefront of activity, lost their urgency and were submerged into the drafting of city plans and zoning ordinances until the 1960s. Only periodic resurgences of social and ecoromic issues such as job support programs and public housing reawakened planners to the comprehensive framework first proposed in 1909.

In order to further pursue the historical impetus for the city planning movement, the authors examined the literature and conference reports published between 1909 and 1925 . Initial investigation revealed the predominance of Benjamin C. Marsh and Lawrence Veiller. With additional research, the polarity of opinions between the two men became evident and lecause of their diversity and influence on planning, we have focused our analysis of the historical period on their viewpoints and activities.

Marsh and Veiller were both active in the emerging planning profession, attended the national meetings and were well known and articulate reformers of the progressive period. And although most planners and reformers did not propose as extreme solutions to the urban problems as did Marsh and Veiller, the conflict of views between them and the way in which that conflict was resolved significantly influenced the direction of planning thought for many years to come. By viewing the emerging planning profession through the words and theories of these two men, we feel the historical implications of planning will be adequately served. 


\section{CHAPTER I}

THE NEW URBAN EXPERIENCE

"The city has woven our lives into the lives of others." (Frederic C. Howe, 1905)*

During the last week of May, 1909, a group of reformers, engineers, architects, and politicians met in Washington, D.C. under the auspices of the New York Committee on the Problems of Congestion of the Population. The purpose of the gathering was the First National Conference on City Planning and the Problems of Congestion. This conference signified the emergence of a new concept of city planning to compete with the "City Beautiful" style of planning which had dominated since 1893.

The "new planning" differed from the "City Beautiful" not only in its form, but in its underlying causes as well. The forces which shaped city planning in the Progressive era were those which also influenced reformers in housing, social work, sanitation, and urban politics. These forces included new techniques in manufacturing, advances in communication and transportation, major changes in the ethnic and cultural make-up of urban centers, and the rapid and costly expansion of the centers themselves, both in terms of population and in physical size.

These forces, which can be characterized as the new urban experience, formed the underlying basis for much of Progressive reform in general and were particularly influential in the development of the city planning movement.

* The City: Hope of Democracy (New York: Scribner's, 1905), p. 24. 
This chapter will examine changes in the American city in the decades following the Civil War. The discussion will focus on two processes, industrialization and urbanization, and the ways in which they altered the form and function of cities and the social relationships within them in the last third of the nineteenth century.

The walking city of the early nineteenth century covered from five to eight square miles. Its primary function was that of a commercial center serving a relatively small agricultural hinterland. Population in all but the largest cities tended to be ethnically homogeneous. The small size of the commercial city meant that neighborhoods tended to be mixed. Members of all economic classes lived within great proximity of one another, and, as a result, the class barriers tended to be far less rigid than those which characterized the later industrial city. Business revolved around the individual enterprise or partnership, and production was geared primarily to goods for local consumption or relatively crude agricultural implements for use in the rural hinterland. ${ }^{1}$

Because of its small size and simple economic structure, a sense of community existed for members of all classes, and a common set of values and mores played a significant role in organizing society. ${ }^{2}$

As urbanization and industrialization increased in the second half of the nineteenth century, much of this "traditional" way of life disappeared. Transportation improvements, notably the coming of the horse-drawn street railway, had the 
effect of drastically changing the size of the city. The walking city began to expand physically into the modern metropolis as the street cars opened large new tracts of land to settlement. And with the replacement of the horsedrawn vehicles by electric cars in the $1880^{\prime} \mathrm{s}$ and the $1890^{\prime} \mathrm{s}$ in most cities, the transformation from the walking city was virtually completed. 3

The process of industrialization, of which the transportation advances were but one element, had a significant impact on the growth development of cities in the latter part of the nineteenth and early twentieth centuries. Although it originated in Pawtucket, Rhode Island in the 1790's, the Industrial Revolution reached national significance in the decades following the Civil War. By the 1870's, the commercial city was steadily being absorbed into a system of cities tied into a national, rather than local, economy. 4 The resultant industrial city tended toward "the creation of a specialized base or cluster of bases which proceeded at a rapid rate between 1870 and 1920." 5 This increasing specialization of function profoundly altered both the relationship of the city to the larger society and the nature of social interaction within the city itself. These changes will be discussed in more detail below.

The expansion of the city as a result of transportation innovations and the growth of industry in the urban setting had mutual benefits. The geographic extension of the city along the routes of the new transit lines had the effect of creating tremendous demand for various producers' goods. 
Street car lines demanded more steel and the expansion of various municipal services such as water, sewer, lighting and communication systems led to an increased demand for lead pipes, copper wire, and numerous other manufactured goods. Furthermore, expanding populations of these new areas adjacent to the traditional city created vast new markets for new consumer goods. 6 This increased demand for manufactured goods and public services in turn, led to an increased demand for labor, and served as a "pull" factor in attracting even larger numbers of people to the cities.?

This large-scale growth of cities had a profound effect on the make-up of American society. Just prior to the Civil War only slightly more than 6 million people lived in the nation's cities. By 1920 that figure had increased to over 54 million, and for the first time in its history, the United States had a population which was more urban than rural. 8

The composition of this new urban population was particularly significant. While some of the increase resulted from an excess of births over deaths, it has been estimated that natural increase accounted for only about $35 \%$ of the gain. 9 The remaining $65 \%$ was the result of migration, both from the American countryside and from outside the United States.

The rural-to-urban flow within the United States was at least in part influenced by the emergence of the industrial city. New farm implements such as the mechanized McCormick reaper and the application of scientific techniques to agriculture greatly increased output while significantly reducing the demand for rural labor. The resultant "excess" farm 
population was drawn to the cities to seek employment in the very industries which had been instrumental in pushing them out of the agricultural labor market. ${ }^{10}$

This internal population shift was especially dramatic in the last two decades of the nineteenth century. In the 1880's, for example, $40 \%$ of the nation's rural townships declined in population, while in New England the number was 60\%. Furthermore, by 1910, $20 \%$ of the nation's 45 million urban dwellers had come from the rural countryside. ${ }^{11}$

But by far the largest numbers of new city dwellers came from abroad where similar advances in agriculture had resulted in a surplus of labor as well. These new urbanites had a tremendous impact on the growth of cities. By 1910, 40\% of the population of New York City consisted of foreign borm, while another $38 \%$ were the children of foreign or mixed parents. New York was not unique in this. Boston by 1910 had a population which was 36\% foreign borm and 35\% of Chicago's population consisted of immigrants. The table below gives some indication of the impact of immigration on a number of the nation's largest cities.

Population Compositions of Major Cities, 1910

\begin{tabular}{|c|c|c|c|c|c|c|c|}
\hline & \multirow[b]{2}{*}{ Total } & \multicolumn{2}{|c|}{$\begin{array}{c}\text { Foreign Born } \\
\text { White }\end{array}$} & \multicolumn{2}{|c|}{$\begin{array}{c}\text { Native Bom } \\
\text { of Foreign or } \\
\text { Mixed Parentage }\end{array}$} & \multicolumn{2}{|c|}{ Black } \\
\hline & & Number & $\%$ & Number & $\%$ & Number & $\%$ \\
\hline New York & $4,766,883$ & $1,927,703$ & 40.4 & $1,820,141$ & 38.2 & 91,709 & 1.9 \\
\hline Chicago & $2,185,283$ & 781,217 & 35.7 & 912,701 & 41.8 & 44,103 & 2.0 \\
\hline Philadelphia & $1,549,008$ & 382,578 & 24.7 & 496,785 & 32.1 & 84,459 & 5.5 \\
\hline St. Louis & 687.029 & 125,706 & 18.3 & 246,946 & 40.0 & 43,960 & 6.4 \\
\hline Boston & 670,535 & 240,722 & 35.9 & 257,104 & 38.3 & 13,564 & 2.0 \\
\hline Cleveland & 560,663 & 195,703 & 34.9 & 223,908 & 39.9 & 8,448 & 1.5 \\
\hline Baltimore & 558,485 & 77.043 & 13.8 & 134,870 & 24.1 & 84,749 & 15.2 \\
\hline Pittsburgh & 533,905 & 140,436 & 26.3 & 191.483 & 35.9 & 25,623 & 4.8 \\
\hline Detroit & 465,766 & 156,565 & 33.6 & 188,255 & 40.4 & 5,741 & 1.2 \\
\hline Buffalo & 423,715 & 118,444 & 30.0 & 183,673 & 40.4 & 1,773 & 0.4 \\
\hline San Francisco & 416,912 & 130,874 & 31.4 & 153,781 & 36.9 & 1,642 & 0.4 \\
\hline Milwaukee & 373,857 & 111,456 & 29.8 & 182,530 & 48.8 & 980 & 0.3 \\
\hline Cincinnati & 363,591 & 56,792 & 15.6 & 132,190 & 36.4 & 19.639 & 5.4 \\
\hline Newark & 347,469 & 110,655 & 31.8 & 132,350 & 38.1 & 9,475 & 2.7 \\
\hline New Orleans & 339,075 & 27,686 & 8.2 & 74,244 & 21.9 & 89,262 & 26.3 \\
\hline Washington & 331,069 & 24,351 & 7.4 & 45,066 & 13.6 & 94,446 & 28.5 \\
\hline
\end{tabular}

Source: Derived from 1910 U.S. Census.

Reprinted from: Chudacoff, H. The Evolution of American Urban Society, p. 91 . 
Industrialization, advances in communication and transportation, and the massive influx of new migrants combined to transform the traditional form of the city. The center of the preindustrial city had been the prestige area. It was the site of most religious and governmental institutions as well as the center of commerce. The difficulty of communication also resulted in the center serving as the home for the urban elite. ${ }^{12}$ As these central districts became foci of large-scale industrial and commercial activity, and the transportation and communication improvements of the last half of the nineteenth century made "suburban" living possible, long time residents began to abandon the inner city for the new areas, and unskilled workers took their place. As the immigrants filled the neighborhoods, landlords converted single family dwellings to multi-family use and allowed buildings to deteriorate through overcrowding and neglected maintenance. ${ }^{13}$ Rear yards and surrounding grounds were filled with cheap, poorly constructed new structures which could rent for relatively low prices. As a result of this and the easy access which these locations afforded the newcomers to low skill job centers, migrants, from both rural America and abroad, were attracted to this residential fringe.

In addition to the changes in the social structure which resulted from the growth of a new urban population, the emergence of new industrial forms had sizable impact on social relations. Segregation based on class, race, and ethnic origins became far clearer than they had been in the commercial 
city. But, perhaps more importantly, the individual was much less responsible for his/her own economic destiny. With the development of the modern factory system and the production of large quantities of standardized goods for national markets, opportunities for economic advancement became increasingly controlled by "remote impersonal forces--the absentee capitalist, the laws of the marketplace, technological innovation."15

In summary, then, the nature of the city which faced the reformers at the turn of the century differed substantially from that which existed at the close of the Civil War. The forces of urbanization and industrialization and all that they entailed had greatly altered the face of America during the last half of the nineteenth century. And the reform movements which developed during the period drew much of their impetus from the need to deal with these changes. The movement for city planning, as part of this reformist program, must be seen against the backdrop of these twin processes in order to be properly understood. The early planners were reacting in part to what they perceived as the misery of the urban ghetto. But such humanitarian concerns were far from the only motivating force behind their actions. Planning, like other reforms, reflected a desire to return a sense of order to this new industrial city. ${ }^{16}$ But in attempting to restore order, planning was also influenced by the industrial complex with which it was attempting to deal. Planners adopted models from business for their organizations. Business goals, most notably that of efficiency, became their goals so that in time 
they came to see their role as that of serving the businessman rather than the immigrant.

The following pages will examine the growth and change which occurred in the planning movement following the 1909 Washington Conference. The impact of the larger context of reform on planning will be investigated, as will the conflicts within the movement itself. Finally, the way in which these conflicts were resolved, and the influence of this resolution on the current practice of planning will be the focus of the concluding chapter. 
CHAPTER II

THE PROGRESSIVES AND CITY PLANNING

"The spirit of the new age was, therefore, one of reform, not of revolution. It called for no evolutionary or utopian experiments, but called for the steady and progressive enactment of measures aimed at admitted abuses and designed to accomplish tangible results in the name of public welfare." (Charles and Mary Beard, 1921)*

During the first two decades of the twentieth century, reformers who had been active since the middle of the $1880^{\prime} \mathrm{s}$ became a dominant force in politics at the national, state and local levels. It was also during these years that the basic institutions which they established took the forms which we know today.

This chapter will survey the general trends in urban reform of the Progressive era through an examination of their application to such areas as education, social work, and governmental reform. Then it will show how the very same issues were reflected in the new city planning movement.

The city planning movement as it developed from 1909 onward was deeply influenced by the same trends which characterized urban reform in general during the Progressive era. These trends included concern with efficiency, organization, and the application of "science" to decision-making, the development of a professional consciousness, and a greater role for businessmen and business methods in the public sphere. Although they often represented conservative influences, these trends must also be seen as an attempt to re-impose some sense of order on

* History of the United States (NY:Macmillan Co., 1923), p. 552. 
a society which was rapidly growing and changing. Thus, unlike some of the earlier agrarian "revolts" these modern reform movements were firmly rooted in the urban industrial world. Rather than trying to deny that world, they must be viewed as an attempt to exercise some control within it. ${ }^{1}$

Yet Progressive reform was also marked by contradictions. In many cases reformers were moved by the very real problems which faced workers and immigrants in urban ghettoes. But the methods and goals which they chose in dealing with these problems often worked against the interests of those same groups.

Changes in the nation's economic structure were particularly important in establishing the underlying conditions for reform. As was pointed out in the previous chapter, the postwar economy was characterized by the demise of the individual enterprise and its replacement by the corporation. As this occurred, production ceased to be for local markets, but instead was for national distribution. The large scale of these new industrial enterprises made individual responses to the problems which they generated ineffective. Those groups which dealt with issues which were clearly economic, such as labor unions, farm-commodity organizations and the like were perhaps the first to adopt business models in order to effectively deal with problems which were no longer local in scope. 2 But reformers, impressed by the productivity and overall success of the corporation soon began to organize and operate on the same scale. The establishment of national conferences and 
organizations to deal with such diverse areas as charity reform, child labor, educational administration, and housing reform suggest the impact of business form on reform activity. Indeed, even the champions of the neighborhood, the settlement house workers, felt the need to establish a national association in order to insure their effectiveness. 3

The adoption of business models by reformers is perhaps most clearly evident in the area of governmental reform. Reformers in this area were particularly taken with the idea of running the city as a business. Thus, among the structural reforms are found such innovations as the city commission, the abolition of ward representation, and the ultimate of the city-as-business governments, the council-manager system. In theory, the aim of such reforms was the improved administration of urban government which would result from its functioning as a corporate business in its entirety "rather than as a hodgepodge of associated localities."4 In actual practice, the results were often a reduction of working class-immigrant power and a concentration of control of government in the hands of the middle and upper class businessmen and professionals. 5

In addition to organizational models, reformers were impressed with the ideal of efficiency and the technique through which it became operational, scientific management, as keys to productivity and problem solving. Indeed the concept of efficiency became so universally accepted in the decade after 1910 that Raymond Callahan has suggested that the era be dubbed "The Age of Efficiency."6 
The initial arguments in favor of scientific management were developed for application in industry in an effort to reduce waste of time and materials in the production process. But the technique received such publicity that in the public mind it became applicable to virtually all aspects of life. Lectures, articles, and editorials extolled the virtues of scientific management in even such "inefficient" institutions as church and the home. Indeed, one writer went so far as to set out to the minute the amount of time a pastor should spend praying, visiting parishioners, and the like.?

But beside these somewhat extreme examples, the impact of efficiency and "scientific" decision-making was clearly evident in a number of progressive reforms. This was one goal in the establishment of the Charitable Organizations Societies, with their centralized registration techniques and the gradual spread of "scientific charity." 8 The drive for efficiency is even more clearly evident, however, in the reforms which occurred in urban education during this period. The elimination of ward representation on school boards, the reduction of size of these bodies, and the growing importance of professional administrators trained to manage the "business aspect" of school systems with little regard for educational goals, all represented attempts to improve the efficiency of urban school systems. 9

The outcome of these reforms in education was similar to the result of the structural reforms in city government. Schools were more centralized, and thus less able to respond 
to the needs of urban neighborhoods 10

A final development during the Progressive period, which was at least in part the result of the drive for increased efficiency and business-like organization was the emergence of a new class of professionals. Unlike the traditional professionals, doctors, lawyers, the clergy and the like, these new professionals justified their claim to that status on the basis of their understanding and control of skills and techniques necessary for the functioning of the modern urban industrial society. But as Lubove points out, expertise alone is insufficient to justify a claim to professional status. The members must internalize a shared sense of community and a set of values. And in many, if not all instances, these are reinforced by institutional agencies of control such as professional schools and associations. 11 This pattern is evident in social work, business administration, public administration, and educational administration, to name but a few.

The new city planning movement as it developed after 1909 reflected the same forces which were at work in other reform movements of the Progressive period. The adoption of business models is reflected in the establishment of the National Conference on City Planning, a stable of virtually all Progressive reform movements. And the call for an independent planning Commission, theoretically to be "above politics" reflected the same forces which led to the establishment of commission and council-manager governments. Although the early practitioners of the"science" of city 
planning came from such diverse backgrounds as housing reform, architecture, engineering, social work, and the law, as the movement gained strength, it very quickly developed a culture of professionalism akin to numerous other new professions. The first movement in this direction can be seen as early as 1913. At the Fifth National Conference on City Planning held in Chicago, George B. Ford, one of the most influential of the early planners, pointed out that the "science of city planning" existed as an entity distinct from those professions from which most of its early practitioners initially came.12 The establishment of a professional society, the American City Planning Institute, and a professional School of City Planning at Harvard soon followed.

City planners, like other reformers, quickly embraced the goal of efficiency as their ultimate objective. Conference reports, speeches, and journal articles all make this point. In 1912, for example, Arthur W. Brunner told those in attendance at the National Conference at Boston that:

It is rumored that the city plan will be ruinously expensive and plunge the city into debt. We know that the contrary is true and that it simply means the exercise of such prudence and foresight as are necessary to secure the success of any business enterprise... City planning is not a fad...it is an economy.13

The following year, George B. Ford advocated the application of "science" to city planning, and again in 1914 he alluded to the efficiency aspect of planning in an article for American City when he wrote:

[In] a comprehensive, practical plan each part would fit in with each other part as in the ideal manufacturing plant.14 
The concern with efficiency, indeed, was so great that even those who proposed more radical solutions to the problems of congestion were not immune from its influence. Even Benjamin Marsh, the leader of the radical faction, called for a "businesslike approach" to the implementation of city plans. ${ }^{15}$

The acceptance of business models and goals by planners had a significant impact on the direction of the movement. In fact, in a very brief period, the primary concern of the field changed substantially. When the planners had gathered in Washington in 1909, they had come to investigate altematives for dealing with the problems which faced residents of the immigrant and migrant ghettos of the industrial cities. They discussed solutions which ranged from housing code enforcement to radical economic change. But as planners began to see themselves as professionals schooled in specific technical skills, and as they came to accept more fully the idea of the city as a business and the ideal of business efficiency in its operation, planners also began to identify themselves with the business community in the same way that their predecessors in the "City Beautiful" movement of the nineteenth century had. By the 1920 's it was rare to find references to the problems of the poor in any planning writings. The order of the day was more clearly stated by John Ildher of the U.S. Chamber of Commerce in a speech at the 1921 Conference. "Our first consideration in city planning," he said, "must then be given to the needs of business."16 
Progressive reform had within it a series of contradictions. It attempted to rationalize and humanize a rapidly changing, often brutal world. But in approaching its task through adopting business methods and goals, and the development of professional decision-makers, reformers effectively reduced individual and neighborhood impact in the decisionmaking process.

Planning, born in this era, faced many of the same issues and had, unfortunately, many of the same results. The direction of planning was not inevitable at its outset, however. The early conferences saw several attempts to infuse the movement with a sense of the need for major changes in society. The following will examine the debate between two leaders of the early movement, Benjamin C. Marsh and Lawrence Veiller, and suggest ways in which the outcome of their struggle helped to establish the direction which planning was to follow in the years ahead. 
CHAPTER III

CITY PLANNING AS PRESENTED BY BENJAMIN C. MARSH AND LAWRENCE VEILLER

"In both cases planning and replanning the greatest obstacle to successful achievement is an exaggerated sense of property rights and the desire to gain personal advantage." (Benjamin C. Marsh, 1915$)^{*}$

An integral aspect of the Progressive Period, City Planning shared characteristics and methodologies with other reform movements. During the Progressive Period, efforts to "reform" government, education, urban development and social welfare often translated into a desire for order, efficiency, and clarity. Central to the uproar over the decay and congestion in the urban areas of the country was the diversity of opinion among the reformers as to the role of the large numbers of urban poor, especially the foreign born and their families. Perceived both as victims and perpetrators of urban problems, the foreign borm were constantly discussed, dissected and described in graphic if not always gracious language. Contemporary studies, such as The Tenement House Problem, clearly defined the housing problem in terms of ethnic groupings, an analysis first put forth by Jacob Riis in the $1890^{\prime} \mathrm{s}$.

Because many of the contemporary city planners of the 1910's saw the close connection between immigration and poverty, slums, and housing, they concentrated their efforts on the issue of congestion. For the first few years the City Planning confer-

\footnotetext{
* "Industry and City Planning," Town Development (August 1915), p. 115 .
} 
ences were entitled The Conference on City Planning and Congestion.

Within the Progressive Era, the alliance between planning and housing reform set the tone for the future direction in city planning. To many reformers, planning was a suitable vehicle for the establishment of order and efficiency. Subsequently, a desire for these elements promoted the utilization of housing regulations and standards and ultimately the development of districting or the zoning of urban regions. Reformers who already relied on the minimum standards methodology for solutions to the problems of overcrowded cities naturally gravitated to the new districting concept of city planning.

The awakening of city planners to the problems of congestion and housing emerged out of a rejection by members of the profession of the theory of planning which emphasized civic centers and the persistence of city beautification. Previous attempts at city planning had dealt primarily with the construction of municipal monuments and of imposing public buildings. This construction and design process conflicted with the budding social and government reform movements, discussed in the previous chapter. Operating within this atmosphere, city planners and those interested in the functioning and formulating of the city scene could not ignore the problems of the urban poor.

George B. Ford said in 1912, "No city begins to be well planned until it has solved its housing problem." 1 In an appeal to the sensibilities of his colleagues, Ford continued, 
"...can we calmly help the city spend on extravagant public monuments that money which has come from the taxes on the poorman's hovel while the worker in the factory is rushing to an early grave because the city failed to see its duty in providing him with those working conditions which are his absolute right? Yet such are the questions we have to confront." 2 Overcrowding in the city, whether in housing or in the traffic of the streets could not be overcome by public monuments and buildings. If the planners were to make an impact on the face of the city, the issues had to be confronted. The conference meeting reports indicate this confrontation. But an awareness of a problem and the development of viable solutions are two separate steps. It is upon this transitional bridge between identification and action that the planning movement framework was formalized. Although most planners possessed more moderate viewpoints the polarity between Benjamin Marsh and Lawrence Veiller illustrates the formalization of the planning movement. Because of the contributions by Marsh and Veiller to the transformation of housing reform to the zoning of usages of land, their explanations and rationale for contemporary planning efforts provide an especially educational and at times colorful account of this period in planning history.

Previous to their city planning affiliations, Marsh and Veiller were involved in various reform activities representative of the Progressive period. Benjamin Clarke Marsh, a university trained economist, received a BA from Grinnell 
College (Iowa) and attended the Universities of Chicago and Pennsylvania for graduate studies. Marsh was born in Bulgaria in 1877 to missionary parents. Previous to planning involvement, Benjamin Marsh's association with the problems of congestion and poverty was through his experience as special agent for the Philadelphia Society for Organized Charity from 19021903 and as executive secretary of the Pennsylvania Society to Protect Children (1903-1907). In his capacity as executive secretary for the New York Committee on Congestion of Population, Marsh participated in the organizing of the first conference on congestion and planning, held in Washington, D.C. in 1909. Marsh, an early planning advocate, wrote and published An Introduction to City Planning: Democracy's Challenge and the American City (1909). A proponent of an economic solution to urban problems, Marsh combined the single tax philosophy of Henry George with a faith in the abundance of the resources available to the American economy to form his own theories and strategies.

Lawrence Veiller, according to his own account, began his involvement in housing reform because "he decided improvement of housing was a beginning point for reform."3 Veiller, who was born in 1872, graduated from City College in the late $1880^{\prime}$ 's, received his initial exposure to the problems of tenement life during his years as a resident of University Settlement in New York's Lower East Side and his activities with the East Side Relief Work Committee during the depression of 1893. While on the staff of the New York City Tenement Housing 
Department from 1901-1907, Veiller researched and wrote on all aspects of overcrowding and substandard housing in New York. In 1913, with Robert W. DeForest, Veiller edited The Tenement House Problem which included, in two volumes, articles pertaining to overcrowding, ethnic housing preferences, crime, and a proposed tenement housing code, parts of which were subsequently utilized in many cities. It was in his capacity as director of the National Housing Association that Veiller became a leader in the city planning and zoning movements. He attended the second city planning conference in 1910 and delivered an address entitled "The Safe Load of Population on Land." As a strong advocate of regulation and codes, Veiller influenced the direction of planning theory developed at the initial meetings and conferences.

Although both Marsh and Veiller were speaking to the issues of overcrowding and poverty and to similar audiences, Marsh presented a more pleading appeal to action while veiller assumed a caustic tone toward the urban poor. Of course the differences in their argument lay in the specific remedies and analyses, but their tones do indicate to the reader an attitude toward the poor and their problems. Marsh called for the government to intervene economically to solve the problems of overcrowding while veiller blamed the victims of overcrowding for their predicament and proposed stricter regulations to remedy the housing situation. The polarity of the planning profession was evidenced within many of the other reform movements of the Progressive Period, such as the con- 
tradictions between enforcement of regulations and codes and their relationship to the problems of urban poverty.

The search for efficiency and order which came to be symbolic of city plans was also included in the programs of Benjamin Marsh. In his address to the First Conference on City Planning and Congestion, Niarsh outlined a program for the development of city planning in America. The steps included fact finding, publicity of results, and the securing of legislation to allow city planning. His program, which emphasized public knowledge and the utilization of government resources, was very similar to those proposed in other reform areas such as public health and city management. Further emphasizing the efficiency aspect of planning, Marsh spoke directly about the cost of congestion to the citizens. "The reason for city planning in these cities is to be found preeminently in the fact that much of the planning that has heretofore been suggested has been a bonus to real estate and corporation interests without regard to the welfare of the citizens. The total cost of congestion of population we can only estimate; the known costs are a tremendous burden on the taxpayer." 4

It was Marsh's emphasis on redistribution of wealth that alienated many members of the reform community as well as divided the small number of city planning supporters. Since private business was the main support system for planning, no other prominent planner publicly took as anti-business a stand on the tax and congestion issues as Marsh. Charles Mulford 
Robinson criticized a policy of Marsh's which called for a radical change in taxation. Even Henry Morganthau, a banker from New York, who supported the Committee on Congestion of Population through pledges of money and office space, in an attempt to repudiate Marsh ended his chairmanship of the committee and thus repealed his backing of the Marsh campaign. Robert DeForest, a housing reformer and partner and coeditor on many of Lawrence Veiller's ventures, publicly attacked Marsh's theories. The National Housing Association, formed in 1910 with DeForest as president, was also openly hostile toward Marsh. A reply from the Harvard Department of Economics to an inquiry concerning congestion by Marsh in 1913 read, "We must reckon with the fact that people flock to the congested districts because they want to be there; just as, for instance, single taxers flock to membership in congestion committees because they want to be there." 5

Foremost a housing reformer, Lawrence Veiller represented a vein of sociological thinking prominent during the preWorld War I period. In reaction to ethnic overcrowding, Veiller promoted a strategy of regulating tenements by the development and enforcement of city codes. Many reformers shared Veiller's view that by making the overcrowding and occupancy of tenement slums illegal, residents would be forced to alter their living arrangements and habits.

The studies conducted and utilized by Veiller to support this viewpoint were highly quantitative, relying on pages of statistical information and charts indicating rates of death, 
numbers of families per unit dwelling, and the height of tenement buildings. Also testimonies of residents were used to explain the poor conditions. Veiller's emphasis was always on the unrealized desire of American (native born) people to move away from the crowded cities, and the foreigners' inability or unwillingness to change their living situations.

Frequent debates between Marsh and Veiller took place in planning meetings. The proceedings of the second national conference held in Rochester, New York, on May 2-4, 1910 , contain an important exchange between the two reformers, both of whom were members of the Executive Committee.

At the conference, four sets of papers were delivered; the topics were: "Causes of Congestion of Population," "The Prevention and Relief of Congestion of Population," "The Circulation of Passengers and Freight and its Relation to the City Plan" and "Some Problems of Legal and Administrative Procedures Affecting the City Plan." Marsh addressed the "Causes" in the first paper in the section and Veiller presented the second speech which discussed "Prevention and Relief." The speeches indicated the high degree and wide range of disagreement between the two men.

According to Marsh the high cost of land forced the working person to share dwellings with large numbers of people in order to pay the rent in a tenement unit. "Congestion of population is primarily the result of protected privilege and exploitation, and must be dealt with largely as an economic problem and the result mainly of economic conditions." 6 
Marsh emphasized the profit motive of tenement housing and phrased the problem this way:

... the vicious circle in congestion is as follows: Anticipated congestion of population leads the prospective builder of a high tenement to pay at the rate of one to five dollars per square foot to the owner of the land. Having paid the price, the tenement owner claims it is his legal right to crowd people in the tenements, the assessor capitalizes the rentals of the congested lot and increases the assessed value of the lot upon which the landlord must pay taxes, and the landlord in turn claims this as an excuse for charging higher rents."?

In addition to the land cost cycle, the low wages of working people, the inadequate transportation system and the speculative land buying system all provided economic conditions for congestion. Compounding the problems, Marsh saw, immigrants desiring work and family support continued to flock to "the most expensive places to live...in our great cities." 8 Marsh also indicted the bureaucratic structure for promoting the inactivity of slum living especially in the immigrant sections of the cities where, because of the foreigners' ignorance of the language and low supervision of code enforcers, people were living in abominable conditions.

The belief in the sanctity of the home, prevalent in American culture, inhibited the enactment of government regulations to protect tenants. Thus, Marsh did agree with Veiller's push for regulation and legislation, but he regarded the need for regulation only as a symptom of the problems rather than as a solution for congestion and urban blight. Codes and standards might stop the spread of urban decay but would 
not eliminate the already existing slum neighborhoods. Furthermore, enforcement of housing standards would do nothing to raise the living conditions of the poor.

In the afternoon session of the conference, Veiller differentiated between room overcrowding and land overcrowding and between the housing problem and city planning. He stated succinctly:

Room overcrowding, at least as we observe it in America, is an evil bound up largely with the social habits of certain foreign elements of overpopulation, and is no way due to the lack of wisdom with which our cities have been laid out. It is a phenomenon observed chiefly among Italians and Russian and Polish Jews, and other Slavic races that in recent years have come to our shores in such large numbers. It is almost never observed in America among the Germans and French, and only occasionally with the Irish and Negroes. It is rarely found with native Americans. It is due to greed quite as much as to need." 8

When illustrating points concerning congestion and poverty, Veiller often used and manipulated the volumes of statistical information collected by the social scientists. After dismissing the problem of overcrowded tenements as cultural affectations, Veiller claimed that it was the relationship between land overcrowding and city planning which was relevant to the conference deliberations and not the issues of slum and tenement housing. He reiterated the points raised by a previous speaker, the concentration of people. By comparing a high concentration of residents in a wealthy neighborhood in New York with the overcrowded slum dwellings of the Lower East Side, Veiller deduced that high density living is not necessarily 
evil. Thus, the maximum number of people per land unit is not determinable. Then, discrediting the previous speech by Marsh, Veiller said, "We have listened this morning to some amazing and many amusing theories about congestion and $i$ ts causes." 9 He disavowed the economic cause of congestion claiming that since wages were higher in New York, the city of the highest congestion, a relationship between low wages and high congestion did not exist. A similar argument was used on the issue of land speculation. In reference to the high death rate on the Lower East Side, Veiller said that too many elements were involved to "draw inferences either way." Backing away slightly, Veiller acknowledged that, "Be these things as they may, it behooves every city planner to do what he can to prevent congestion and to build our cities so that undue concentration may be avoided... Our task is to see that urban population is wisely and safely housed."10

By 1911, the practice of planning had begun to narrow. As indicated by the conference reports, the view promoted by Lawrence Veiller had been acknowledged by the planning profession. Benjamin Marsh, although listed as a committee member, was not a conference speaker. The causes and implications of congestion were conspicuously missing from the agenda. Further debates did occur between Marsh and Veiller but not at the national conference.

In 1914 a volume of The Annals of the American Academy of Political and Social Sciences was published on the topic of "Housing and Town Planning." The problems of housing and plan- 
ning were discussed in articles by various prominent social scientists. Marsh and Veiller were among the writers. Their two articles continued the debate.

In "Can Land Be Overloaded?" Marsh again raised the specter of concentration and overcrowding when he criticized those reformers who wanted to experiment with high density living even though the high death rate of the overcrowded areas proved the danger of such life styles. Marsh reiterated the economic issues. "It is a very safe assertion that, if the financial profit of the intensive use of land were secured by the community instead of land owners, these latter gentlemen would not find so many advantages in massing people to the acre."11

Consistent with his earlier statements, Lawrence Veiller in "Housing Reform Through Legislation," wrote, "How delightful it would be to be able to believe that all that is needed to bring about proper housing conditions is a change in the economic status of the working people."12 Veiller predated urban renewal with a suggestion that cities should destroy slums before Garden Cities were built even though the housing problem would not be solved. Ignoring the issues of cheap housing and transportation, Veiller claimed that the true housing problem was the inability of the economy to provide decent housing for those who desired it at reasonable rates. The replacement of slum dwellings with more expensive units was cited as one method of handling the housing problem. Supposedly, American people would be willing to pay more rent 
in order to obtain better living conditions.

The emphasis on regulations and minimum standards coupled with the refusal to deal with the basic economic problems of the city caused the city planning movement to develop a separate identity from the reform community. More strongly associated with business and property interests than with urban reform, planning came into its own. Zoning was the tool which facilitated the process. 
CHAPTER IV

THE EMERGENCE OF "ZONING" AS PLANNING

"The first and last and greatest mistake to be avoided in zoning is to try to do it without the active, hearty, and enthusiastic cooperation of the organized real estate interests of the community." (Lawrence Veiller, June 28, 1923)*

The acceptance of zoning as the primary means of city planning heralded a triumph by the supporters of regulations and minimum standards, led by Lawrence Veiller. The use of the district or zone system in the process of city planning was initially suggested to the National Conference on City Planning at the 1911 meeting in Philadelphia. Ironically, Benjamin Marsh, who was outspoken at the two previous conferences, retreated into the background at the 1911 conference.

As it was first presented, districting as a tool was intended to be one element in the development of the plan for a city. In conjunction with the other elements, such things as transportation, parks and playgrounds, and the like, it was felt that zoning could play a role in the improvement of conditions within the congested districts of the urban community.

Over the course of the next fifteen years, however, the importance and function of the zoning tool in planning changed substantially. In fact, by 1918 Andrew Wright Crawford felt it necessary to warn his colleagues that, "We are in danger as city planners of setting a narrow point of view. In all this discussion we have talked only of zoning regulations and

\footnotetext{
* "Mistakes to Be Avoided in Zoning," Address to National Association of Real Estate Boards, 1923.
} 
not of some of the other things in planning which help zoning."1 By the time that the United States Supreme court upheld the constitutionality of zoning in the Euclid v. Ambler case in 1926, that technique had, for all intents and purposes, become planning. And the goals of planning, despite the origins of the movement in housing reform, had ceased to be an improvement of the urban condition, and instead revolved around the provision of an environment in which business forces could function most efficiently.

The first major speech dealing with the subject of zoning, given by Philadelphia Board of Surveys Assistant Engineer, B. Antrim Haldeman, at the 1912 Boston Conference, reflected the concern with the problems of congestion which had been instrumental in leading to the first planning conference three years earlier. However, this speech also reflected the influence of the municipal reformers and the business and real estate interests who in the coming decade and a half were to determine the direction of city planning at the expense of its earlier reform supporters. Haldeman hoped to bring the productivity and efficiency of business to city planning, and it was these aspects of zoning which endeared the process to the business community. As Haldeman put it, "...under a zone system the permanent population of any given area may be determined with a reasonable degree of accuracy. With this factor known, it is possible to forecast the needs of the district with confidence that whatever is done will be done properly, permanently, and economically."2 
The close ties between municipal govermment reformers and city planning are reflected in Haldeman's argument in support of increased public intervention in control of private land use decisions. Government could be trusted to take such responsibilities, he argued, because

Municipal Government in the United States is undergoing an evolution that points toward material improvement, and the time may not be far distant when our cities will be governed as wisely as those of Germany, where the power of the local officials is so great, that only the most capable and trustworthy men dare to be placed in public service....3

The debates over zoning suggest that a new concern appeared after 1912. It was around the idea of protection of existing and future residential neighborhoods that much support for the concept of zoning first crystallized. At the 1914 conference, Lawrence Veiller claimed that planners had the responsibility to "...protect our citizens in the enjoyment of the right to lead a quiet, contented, rational existence...free from the noise, discomfort, and nerve racking atmosphere which generally surrounds our industries." 4 Zoning was critical to this process. However, the motivation for protecting the residential environment was not based on humanitarian concerns. As the committee on the City Plan of the New York City Board of Estimates and Apportionments pointed out in 1916,"...there is a necessary relation between the conservation of property values and the conservation of public health, safety, and general welfare." 5 And at the 1918 Conference on City Planning, Robert H. Whitten discussed the relationship between the protection of residential 
districts and the productive efficiency of workers. "This war World War I has shown that good housing is absolutely essential to efficient production." 6

Initially zoning had the support of the more radical faction of the planning fratemity led by Benjamin Marsh. However, neither the majority of the new planners nor their supporters shared Marsh's social and economic philosophies, and as a result zoning came to serve ends quite different from those for which it had originally been developed. Marsh hoped that zoning would be a technique of government intervention to solve urban problems such as overcrowding, but instead the technique came to be seen as a means of maintaining property values and protecting investments, thus serving the needs of business and real estate men rather than those living in the congested inner city districts. For example, the nation's first zoning law, established in New York City in 1916, had the strong support of the city's real estate interests, who viewed it as a means of bringing a degree of stability to an uncertain land market which existed at the time.? Indeed, the real estate and business communities had so much influence over the Committee appointed by the Board of Estimates to develop the ordinance that even committee member Lawrence veiller refused to sign the committee's final report. 8

New York City planners were not unique in connecting zoning with business support. In 1917, for example, J. Horace McFarland, President of the American Civic Association told the planners at their gathering in Kansas City that city plan- 
ning and business must work hand in hand, and further that "...zoning and districting can be so handled with forethought and wisdom as to assure continuing values, rather than to assure ...the wasting of millions of dollars...." 9

At the 1920 conference in Cincinnati, Cleveland banker W. L. Ulmer expressed even more strongly the businessman's appreciation of zoning. Zoning was, according to Ulmer, "...the greatest stabilizer of property values ever conceived, therefore I feel safe in saying that the lender on mortgages is more vitally interested in zoning than any other one class."10 Two years later at the Springfield, Massachusetts conference, Harland Barthelomew and George B. Ford, both nationally known city planning practitioners, presented case studies illustrating how zoning promoted business and protected property rights in their cities.

The adoption of zoning as the principal element of the city plan also reflected the strength of the influence of the housing regulators and codifiers, and particularly of Lawrence Veiller on the city planning movement. Veiller and the other "housers" who became involved in city planning and who saw the solution to the housing problem as coming through restrictive legislation such as the New York Tenement House Laws of 1894 and 1900, viewed the problems of the city, and in particular the problem of congestion as "...chiefly a problem of good municipal housekeeping...."11 Thus, it is not surprising that this group advocated a similar solution, restrictive legislation or zoning, as the most reasonable, way to deal with 
the larger problems faced by the city. The influence of this group was demonstrated by the inclusion of Veiller on the Committee which drafted the U.S. Department of Commerce's Standard Zoning Enabling Act in 1926.12

Zoning also served the needs of the planners themselves in their struggle to be recognized as a class of professionals distinct from the housing reformers on the one hand and the landscape architects on the other. In an attempt to justify their status, it became essential for planners to identify a particular area of "scientific" expertise. George B. Ford, perhaps the premier advocate of "scientific planning," told the 1913 conference that one of his ambitions was to change "...this hitherto rather capricious procedure into that highly respectable thing known as an exact science."13

Zoning met the aims of the new professionals. The establishment of various use districts differed substantially from the activities of the city beautiful planners. Rather than simply providing attractive public vistas, the new planners, through the use of such techniques as zoning, provided for the establishment of housing patterns, and the location of transit facilities, industrial plants and the like without concern for the form of these elements within their given districts. In addition zoning gave the planners an area of expertise which had at its base some scientific justification. Thus it filled Ford's need for "one and only one, solution to the problems involved."14 
Planners were members of the new middle class, described by Robert Weibe in The Search for $\underline{\text { order }}^{15}$ as specialists in their professions and businesses. These professionals sought to protect their own neighborhoods from invasion by industry, commerce, and multi-family dwellings. With the establishment of districts in which only single family housing was permitted, the new middle class could guarantee their life style. It was possible for the middle class residents to effectively limit residence in an area to those who met certain qualifications of wealth and status. Planners appeared to have recognized this strategy at their meetings. Robert Whitten, for example, argued that "As the home owner is replaced by the renting class, there is a ... decline of civic interest, and the neighborhood which once took a live and intelligent interest in all matters affecting its welfare becomes absolutely dead...."16 Indeed, the prevalence of such attitudes by 1922 led Lawson Purdy, then president of the National Conference on City Planning, to ask his colleagues:

If in planning our cities we increase our parks and open places, have a better street plan and make the homes of the rich more beautiful, is that enough?1?

While Purdy argued that it was not, the continued dominance of zoning within professional practice suggested that his fellow planners did not agree.

Public exhibits, an old tool of the social reformers, were used by planners in an effort to gain additional acceptance of zoning. Exhibits, sponsored by private organizations such as businessmen's clubs, were displayed in city halls and libraries. Some exhibits traveled from city to city; others were localized 
attempts at public education. Visual and tactile displays were designed for viewing by the general public. More to inform than to obtain support, these exhibits were consistent with the social welfare aspects of the profession, and often were incorporated into educational efforts by other municipal organizations such as public health commissions and playground programs. By showing the local people the potential and actual achievements of city planning, the profession could substantiate the "public welfare" doctrine of city plans and zoning ordinances. For, although they were intended to attract wide audiences, the exhibits were not designed to encourage public participation in the decision-making process. In this pre-tv and radio era, these displays offered a means of information dispersal which facilitated compliance with the new regulations and standards.

Another vehicle for planning publicity was the annual conference on city planning which met each year in a different city in the United States and Canada. Nayor Fitzgerald of Boston explained this technique when he welcomed the conference participants to his city in 1912.

It is a happy custom that leads the chief national societies to move the seat of their convention each year from one city to another. In this way the members become better acquainted with their own country, and even for men of large experience and wide travel like yourselves, there is instruction to be derived from personally observing the evidences of growth and change that are constantly going on. 18

At the same conference, concern for planning acceptance prompted George B. Ford to ask for more conference time to 
discuss education techniques. Thus the assembly voted "... that Executive Committee be requested to finance the popularization of city planning." 19

Three examples of literary and visual planning propaganda illustrate the exclusion of public opinion and the inclusion of business interests in the planning process. The first example, the Metropolitan City Planning Exhibition for City and Town Advance, was arranged by the Council of Fifty, a civic organization in Boston. The exhibit was displayed at the State House from November 12 to November 20, 1915 by the Council which was a representation of "civic and social organizations interested in an adequate and practical plan for the development of the Boston District." 20 For the purpose of education, representatives from each planning board in the Boston District (metropolitan Boston) met and were joined by delegates appointed by the mayor and govemor. Membership, although theoretically open to the public, was limited to those directly involved in planning activities such as real estate brokers, engineers, municipal reformers, architects and city planners. The public was invited to view the exhibit but not to participate.

Displays at the exhibit included information centers sponsored by the American City Bureau, booths and tables with descriptive data about local planning projects, and representatives from city departments illustrating their specific functions. Coordination of the exhibit with the third annual conference of Massachusetts City and Town Officials added to the informational impact of the displays as well as expanded the potential audience. 
In 1916 another interesting exhibit was developed. This one was a traveling national display on The War and City Planning and Housing. This exhibit was sponsored by the Committee on Town Planning of the American Institute of Architects. Seizing the opportunity to show the need for general city planning, the committee used the European disaster to illustrate the potential of city planning.

A third promotional attempt was made in 1920 on a different level and through scholarly and professionally sanctioned means. A Nation Plan, A Basis for Local Planning by Cyrus Kehr, was delivered at the American Civic Association meeting in Amherst, Massachusetts on October 14, 1920 and was subsequently published as a book incorporating $\underline{A} \underline{\text { World }} \underline{\text { Plan }}$ and subtitled $\underline{A}$ Basis for Coordinated Physical Development of the United States of America. Kehr's plan emphasized the need for regional approaches to planning.

By the middle of the $1920^{\prime} \mathrm{s}$, the educational campaigns of the planners had paid off. Planning, particularly as represented by zoning, had been firmly accepted. The 1922 Conference proceedings contain a list of nearly 300 cities, including most of the nation's major municipalities, scattered throughout 31 states, which had plans, and in most cases zoning. 21 But planning as it was carried on through zoning was far different from that which Benjamin Varsh had envisioned in 1909. By 1926, the year of the Supreme Court's Euclid decision, the "new" planning had become essentially as conservative a force as the city beautiful movement which it had come to replace. The goals of efficiency, order, and the preservation of property values were those of the businessman, 
the professionals and the elite of the city. Planning's growing professionalism and demand for technical skills served to make planning even more inaccessible to the democratic political process.

Finally, the emergence of the concept of "public welfare" as a guiding force for zoning misrepresented the rationale of the new planning process. For the "public welfare" or "interest" was in fact an interpretation of the interests of businessmen and professional people, the upper class of most cities. It was those people who embraced zoning and planning in their search for order and efficiency in a changing urban scene. City planning took the form which was to dominate its practice for at least the next forty years; a form which was explained succinctly by the businessman chairman of the Jacksonville, Florida Planning Commission at the 1926 Conference: "You and I as businessmen have the leadership of these men, as technicians." 22 
CHAPTER V

CONCLUSION

"There was another thing that disturbed me about Environmentalism. That was the way it always seemed to favor the status quo. For people who found the present circumstances to their liking, it offered the extraordinary opportunity to combine the qualities of virtue and selfishness." (William Tucker, "Environmentalism and the Leisure Class," 1977)*

The people who first met at the First National Conference on City Planning and Congestion in 1909 came from a wide variety of reform experiences. Their interpretations of the problems confronting the industrial city and the role which city planning would play in the solutions to these problems covered a multitude of social, political, and economic viewpoints.

As indicated by an examination of the opinions of the two prominent reformers, Benjamin Marsh and Lawrence Veiller, there existed a wide range of alternative directions for city planning within the urban reform community. One alternative presented by Benjamin Marsh was a "radical" analysis of the capabilities of city planning. In his view, the problems of the city stemmed from an economic structure which encouraged property owners and businessmen to exploit the immigrants, the workers, and the poor.

In his speeches and writings, Marsh envisioned the use of city planning as a partial solution for the economic ills of the inner city. In conjunction with a tax reform program similar to that of Henry George's, Marsh advocated increased wages and the coordination of such physical developments as

* Harpers (December, 1977), p. 52. 
transit systems, housing construction and industrial relocation. He argued, for example, that transit systems should be both reliable and inexpensive, thus making it possible for workers to live at greater distances from their place of employment and reducing congestion in central districts. Finally, Marsh supported the imposition of controls on land use, but only when combined with these other reforms, in order to end the exploitation of ghetto residents by property owners. In contrast, Lawrence Veiller's view concerning city planning was more limited. He distrusted the economic reformers and held that planning, like his previous work in housing, should establish minimum standards for development. This regulatory approach to urban problems placed primary responsibility upon individual business owners and tenants rather than on the economic system which fostered the dismal conditions of the inner city. Veiller's view was most clearly presented in a speech before the National Association of Real Estate Boards in 1923:

It is not a question of having no laws. No civilized community is going to tolerate a situation by which there shall be no laws safeguarding the community against the evils of dangerous building; the time is long passed when a man can do what he likes with his own.1 That, gentlemen, is not liberty, but anarchy. 1

Marsh's view attempted to combine economic, social and physical solutions into a more comprehensive approach to the urban solutions. A triumph of such a view would have resulted in a form of planning which differs substantially from that which we know today. The type of planning which Marsh advo- 
cated was one which would allow an expansion of the economic and social opportunities of the growing nation to all its people. Its principal concern was not to insure that the most efficient solution, defined from a financial perspective, was developed, but rather that the alternative chosen advanced the quality of life for those in need.

It is not surprising that the Marsh view of planning was not adopted. Such a view was far too disruptive of the status quo to find a sizable number of supporters among the progressive reform community which was active in the city planning movement during its early years. Regulation of land use, as presented by Veiller, was quickly seen as advantageous both to businessmen and middle class professionals, since it protected investments and maintained the homogeneity of "suburban" neighborhoods. Thus, far from providing a solution to urban problems, zoning came to contribute to the worsening of these conditions. George B. Ford and his supporters called for an objective "science" of city planning. This, too, fit into the pattern which was being established in business, government and education during the same period.

Zoning or districting as originally labeled, came directly out of housing regulations and code movements of the early twentieth century. Due to its origins, zoning developed minimum standards, a manner of restrictions rather than prescriptions for the future. Property rights could be guaranteed because owners would be cognizant of the future use of the lands for a longer period of time. An ordering of the city 
scene also meant a direction for property owners who wanted to continue their income in the face of changing technology and life styles. This focus on stability justified a seemingly progressive idea such as planning to the nonprogressive segment of American society. Rather than projecting a future distribution of resources and participation, planning was able through minimum standards to predict a continuance of present patterns of living and working.

The emphasis on regulation had great implications for the direction in which planning was to go during the middle years of the twentieth century. Since the profession became identified with zoning, efficiency, and technical competence during its formative years, the ability of planners to reinvolve themselves in the developments of solutions to the problems of the inner city related to questions of race, poverty and ethnicity has been limited. For, despite the obvious importance of these issues to virtually all urban development decisions, those professional planners who are concerned with the issues first raised by Benjamin Marsh have been segregated from the profession's main body. Yet, social planners do not disregard economic and land use consideration but rather, they choose to emphasize the human consequences of planning decisions. Ironically, it was through the auspices of the New York Committee on the Congestion of the Population that the first conference on city planning was held. Furthermore, it was the inability of the architects and landscape architects of the "City Beautiful" movement to confront effectively the problem of slums and congestion that first prompted the emergence of the "new" planning. 
One attempt at dealing with the inequalities of our society was the advocacy approach to planning adopted in the $1960 \mathrm{~s}$ by a small but articulate segment of the profession. As a direct response to the failures of urban renewal and the recognition of the complexities of urban problems and the necessity of alternative solutions, advocate planners proposed a pluralistic approach to decision-making. Thus, the practice of pluralistic planning encouraged the participation by all citizens and incorporated the socio-economic issues of community into physical planning. ${ }^{2}$ Consequently advocacy allows the inclusion and the publication of alternative plans and avoids the "public welfare" statements of consensus planning.

The 1970's, however, have seen the resurgence of the dominant approach to planning. For example, the environmental planning movement has incorporated the regulation approach to planning and on many occasions fallen victim to the same limitations that characterize zoning. Aiming to protect the "public welfare" often leads to the conservation of the property rights of a few at the expense of the unpropertied majority. By relying on the negative enforcements of ordinances and codes, rather than incorporating factors of socio-economic conditions into futuristic planning, environmentalism is often perpetuating the structure which created the energy and the biological crises. 3

Clearly the Progressive heritage of the planning profession is strong. If, however, we as planners desire to be the force for change which our theories profess us to be, we would 
do well to look for direction to the ideals first proposed by Benjamin Marsh in 1909. 


\section{FOOTNOTES}

\section{Introduction}

1 Joseph Arnold, "City Planning in America," in Raymond A. Mohl and James F. Richardson, eds. The Urban Experience (Belmont, Calif.: Wadworth Publishing Co., Inc., 1973), p. 33. 
Chapter I

1 Harvey Kantor and Maury Klein, Prisoners of Progress

(New York: Macmillan Publishing Co., 1976), pp. $96-97$.

2 Ibid.

3 Zane Miller, The Urbanization of Modern America (New York: Harcout, Brace, Jovanovich, 1973), p. 65.

4 Sam Bass Warner, Jr., The Urban Wildemess (New York: Harper \& Row, 1972), p. 71 .

5 Kantor and Klein, op. cit., p. 98.

6 Niller, op. cit., p. 66.

7 Howard Chudacoff, The Evolution of American Urban Society (Englewood Cliffs, N.J.: Prentice-Hall, Inc., 1975), p. 86.

8 Ibid., p. 179.

9 Miller, op. cit., p. 72.

10 Ibid., p. 73 .

11 Ibid.

12 Gideon Sjoberg, "The Origin and Evolution of Cities," Scientific American, 213 (September, 1965), reprinted in Alexander Caliow, ed., American Urban History (New York:

1973), pp. 6-16.

13 Oscar Handlin, Boston's Immigrants (Cambridge: Harvard University Press, 1959), p. 101.

14 David Ward, "The Making of Immigrant Ghettos, $1840-$ 1920," Annals of the American Association of Geographers.

15 Roy Lubove, The Progressives and the Slums.

16 See Robert Wiebe, The Search for Order, 1880-1920

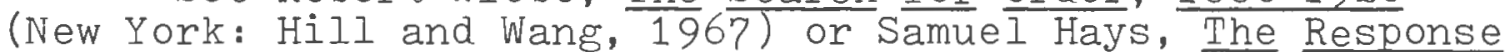
to Industrialism, 1885-1914 (Chicago: University of Chicago Press, 1957). Both discuss this point in some detail. 
Chapter II

1 See Robert Wiebe, The Search for Order, 1880-1920

(New York: Hill \& Wang, 1 $\overline{967}$ ) on this point.

2 Samuel Hays, The Response to Industrialism, 1885-1914

(Chicago: University of Chicago Press, 1957), pp. 69-70.

3 See Allan Davis, Spearheads of Reform (New York: Oxford University Press, 1967) on this point.

4 Samuel Hays, "The Politics of Reform in Municipal

Government in the Progressive Era," Pacific Northwest Quarterly, $55(1964), \mathrm{p} .149$.

5 Ibid.

6 Raymond E. Callahan, Education and the Cult of Efficiency (Chicago: University of Chicago Press, 1962), p. 42 .

7 Ibid., pp. 44-59.

8 Davis, op. cit.

9 Callahan, op. cit., pp. 44-59.

10 Ibid.

11 Ray Lubove, The Professional Altruists (Cambridge:

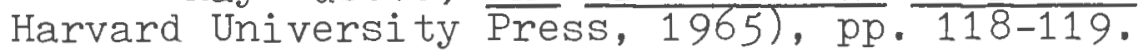

12 Fifth National Conference on City Planning, Proceedings, $1913, \mathrm{pp} .31-45$.

13 Fourth National Conference on City Planning, Proceedings, 1912 , pp. $121-129$.

14 American City, 12 (March 1915), p. 150.

15 Committee on the District of Columbia, City Planning, Hearing, 61st Congress 2nd Session, Senate Document No. 442, $1910, \mathrm{p} .104$.

16 Thirteenth National Conference on City Planning, Proceedings, $1921, \mathrm{p} .17$. 


\section{Chapter III}

1 Charles Beard, The Rise of Urban America (New York: The Century Co., 1912$), \mathrm{p} .360$.

2 Ibid., p. 360 .

3 Lawrence Veiller, Oral History Project of Columbia $(1949), \mathrm{p} .23$.

4 First National Conference on City Planning and Congestion, Proceedings, p. 59.

5 Harvey Kantor, "Benjamin C. Marsh and the Fight Over Population Congestion," Journal of the American Institute of Planners (Nov., 1974 ), p. 426.

6 Second National Conference on City Planning and Congestion, Proceedings, p. 36.

\section{Ibid., p. 74 . \\ 8 Ibid., p. 74 . \\ 9 Ibid., p. 78. \\ 10 Ibid., p. 78 .}

11 "Housing and Town Planning," The Annals of the American Academy of Political Science (January, 1914), p. 58 .

12 Ibid., p. 68 . 
Chapter IV

1 The Tenth National Conference on City Planning, Proceedings, $1916, \mathrm{p} .66$.

2 The Third National Conference on City Planning, Proceedings, $1912, \mathrm{p} .178$.

3 Ibid., p. 187. The record does not indicate the reaction of Mayor John "Honey Fitz" Fitzgerald to this speech. Honey Fitz is considered by some to be among the most corrupt mayors in a city noted for its corrupt politicians.

4 Sixth National Conference on City Planning, Proceedings, 1914, p. 92.

5 "Report on Building Districts and Restrictions," reprinted in Lubove, The Urban Community: Housing and Planning

(Pittsburgh: University of Pittsburgh Press, 1964), p. 97.

6 R. H. Whitten, "The Zoning of Residence Sections," The Tenth National Conference on City Planning, Proceedings, 1918 , p. 35 .

7 Harvey Kantor, "Benjamin C. Marsh and the Fight Over Population Congestion," Joumal of the American Institute of Planners, November $1974, \mathrm{p} \cdot 428$.

8 Mel Scott, American City Planning Since 1880. (Berkeley: University of California Press, 1971), p. $\frac{164 .}{164}$

9 J.H. NacFarland, "The Relationship of City Planning to Business," The Ninth National Conference on City Planning, Proceedings, 1917 , p. 161 .

10 W.L. Ulmer, "Zoning From the Viewpoint of the Lender and Real Estate Mortgages," The Twelfth National Conference on City Planning, Proceedings, 1920, p. 133.

11 Lawrence Veiller, "The Question Box," The Fourteenth National Conference on City Planning, Proceedings, 1922, p. 168.

12 Indeed, Roy Lubove suggests that Veiller wrote the Standard Act, and Veiller himself does little to downplay his role. See his reminiscences, Columbia Oral History Project.

13 George B. Ford, "The City Scientific," The Fifth National Conference on City Planning, Proceedings, $1913, \mathrm{p} .31$.

14 Ibid., p. 31 . 
15 Robert Weibe, The Search for Order, 1870-1920 (New York: Hill and Wang, 1967), chapter 5.

16 Robert Whitten, "The Effect of Zoning on Living Conditions," The Thirteenth National Conference on City Planning, Proceedings, 1921, p. 25.

17 The Fourteenth National Conference on City Planning, Proceedings, 1922, p. 189.

18 The Fourth National Conference on City Planning, Proceedings, $1912, \mathrm{p} .1$.

19 Ibid., p. 172.

20 "Metropolitan City Planning Exhibition for City and Town," pamphlet, 1915.

21 Lawson Purdy, "Better Homes With More Profit," The Fourteenth National Conference on City Planning, Proceedings, 1922, pp. 189-190.

22 Allen D. Albert, "What City Planning Means to the Community," The Eighteenth National Conference on City Planning, Proceedings, $1926, \mathrm{p} .91$. 


\section{Chapter V}

1 Lawrence Veiller, "Mistakes to Be Avoided in Zoning," City Plan Commission (Sept. 1923).

2

For a more complete explanation of advocacy planning, see Paul Davidoff, "Advocacy and Pluralism in Planning Theory," in Andreas Aludi, ed., A Reader in Planning Theory (Oxford: Pergamon Press, 1973), $\bar{p} \cdot \frac{\text { Reader }}{277-296 .}$

3 A good example of this process was illustrated in the Storm King Mountain controversy. See William Tucker, "Environmentalism and the Leisure Class, Protecting Birds, Fishes, and Above All, Social Privilege," Harper's (December, 1977), pp. 4980. 


\section{BIBIIOGRAPHY}

$\underline{\text { Books }}$

Adams, Thomas. Outline of Town and City Planning. New York: Russell Sage Foundation. 1935.

Aludi, Andreas, ed. A Reader in Planning Theory. Oxford: Pergamon Press. 1973.

Beard, Charles A. American City Government (1912). New York: Arno Press, 1970.

Beard, Charles A. and Mary. A History of the United States. New York: Macmillan Co. 1923.

Brownell, Blaine A. and Warren E. Stickler, eds. Bosses and Reformers. Boston: Houghton Mifflin Co. 1973.

Buenker, John D. Urban Liberalism and Progressive Reform. New York: Charles Scribner. 1973.

Callahan, Raymond E. Education and the Cult of Efficiency. Chicago: University of Chicago Press. 1962.

Callow, Alexander B., Jr., ed. American Urban History. New York: 1973.

Chudacoff, Howard. The Evolution of American Urban Society. Englewood Cliffs, N.J.: Prentice-Hall, Inc. 1975. 
Comey, Arthur C., ed. City and Regional Planning Papers By Alfred Bettman. Cambridge: Harvard Univ. Press. 1946.

Davis, Allan. Spearheads for Reform. New York: Oxford Univ. Press. 1967.

Handin, Oscar. Boston's Immigrants. Cambridge: Harvard Univ. Press. 1959.

Hays, Samuel. Conservation and the Gospel of Efficiency. Cambridge: Harvard Univ. Press. 1959. - The Response to Industrialism, 1885-1914. Chicago: University of Chicago Press. 1957.

Higham, John. Strangers in the Land. New York: A theneum. 1965.

Howe, Frederic. Privilege and Democracy in America. New York: C. Scribners \& Sons. 1910.

Hubbard, Theodora and Henry. Our Cities Today and Tomorrow (1929). New York: Amo Press, 1974.

Kantor, Harvey and Maury Klein. Prisoners of Progress. New York: Macmillan Co. 1976.

Kehr, Cyrus. A Nation's Plan. New York: Oxford University Press. 1926.

Kolko, Gabriel. The Triumph of Conservatism. Iondon: The Free Press of Glencoe. 1963. 
Lewis, Nelson P. The Planning of the Modern City. New York: John Wiley \& Sons, Inc. 1916.

Lohman, Karl B. Principles of City Planning. New York: McGrawHill Co. 1931.

Lubove, Roy. Community Planning in the 1920's. Pittsburgh: University of Pittsburgh. 1964.

- The Professional Altruist. Cambridge: Harvard University Press. 1965.

- The Progressives and the Slums. Pittsburgh. University of Pittsburgh Press. 1962.

- The Urban Community. Englewood Cliffs, N.J.: Prentice-Hall. 1967.

Marsh, Benjamin C. Introduction to City Planning (1909). New York: Arno Press. 1974.

Miller, Zane. The Urbanization of Modern America. New York: Harcourt, Brace, Jovanovich. 1973.

Mohl, Raymond A. and James F. Richardson. The Urban Experience. Belmont, Calif.: Wordsworth Publishing Co., Inc. 1973.

Nolen, John, ed. City Planning. New York: D. Appleton and Co. 1916.

- New Ideals in the Planning of Cities, Towns, and Villages. New York: American City Bureau. 1919. 
Pease, Otis. The Progressive Years. New York: George Braziller. 1962.

Scott, Mel. American City Planning Since 1880. Berkeley: University of Califormia Press. 1971.

Warner, Sam Bass, Jr. The Urban Wilderness. New York: Harper and Row. 1972.

Weinstein, James. The Corporate Ideal in the Liberal State. Boston: Beacon Press. 1968.

Wiebe, Robert H. The Search for Order, 1877-1920. New York: Hill and Wang. 1967.

Zueblin, Charles. American Nunicipal Progress. New York: Macmillan Co. 1916.

Reports and Pamphlets

Committee on the District of Columbia. City Planning, Hearings, 61st Congress, 2nd Session. Senate Document No. 442, 1910.

Ford, George B. "What Planning Has Done for the Cities," National Conference on City Planning. 1924.

Kehr, Cyrus. "A Nation Plan - Basis For All Local Planning," American Civic Association. October 14, 1920.

Kimball, Theodora. "A Brief Survey of Recent City Planning Reports in the US," Landscape Architecture Report. January, 1915. 
"Metropolitan City Planning Exhibition for City and Town Advance." (Pamphlet). 1915.

National Conference on City Planning, Proceedings. Vols. 1-22, $1910-1931$.

Nolen, John. "The Importance of Citizen Committees in Securing Public Support for a City Plan Program," National Conference on City Planning. 1924.

Veiller, Lawrence. "Mistakes to Be Avoided in Zoning," City Plan Commission. 1923.

"War and City Planning Exhibit." (Pamphlet). 1916.

\section{Articles}

Hancock, John. "Planners in the Changing American City, 19001940." Journal of the American Institute of Planners. Vo1. 33, 1967.

Kantor, Harvey. "Benjamin C. Marsh and the Fight Over Population Congestion." Journal of the American Institute of Planners. November 1974.

Marsh, Benjamin C. "Industry and City Planning." Town Development. August, 1915. Pp. 115-116.

Tucker, William. "Environmentalism and the Leisure Class, Protecting Birds, Fishes, and Above All Social Privilege." Harper's. December, 1977. Pp. 49-80. 
Other

Kantor, Harvey. "Modern Urban Planning: Origins and Evolution in N.Y.C., 1890-1933." Unpublished dissertation, New York University. 1971.

Veiller, Lawrence. "Columbia Oral History Project." Manuscript. 1949. 